\title{
Year-round measures of planktonic metabolism reveal net autotrophy in surface waters of a Great Lakes estuary
}

\author{
Angela L. Defore, Anthony D. Weinke, Morgan M. Lindback, Bopaiah A. Biddanda*
}

Annis Water Resources Institute, Grand Valley State University, Muskegon, MI 49441, USA

\begin{abstract}
During 2009 and 2010, we quantified monthly changes in plankton metabolism and environmental variables in the surface waters of Muskegon Lake, a Great Lakes estuary connected to Lake Michigan. Muskegon Lake's mean $( \pm \mathrm{SE})$ annual gross plankton primary production (GPP) and respiration $(R)$ rates were $46 \pm 9$ and $23 \pm 4 \mathrm{mg} \mathrm{Cl}^{-1} \mathrm{yr}^{-1}$, respectively. GPP: $R$ ratios of 0.6 to +4.8 with a yearly mean of $2.0 \pm 0.3$ indicated that the surface water of Muskegon Lake was net autotrophic during all but the winter months under ice cover, when it was in a near carbon balance to slightly heterotrophic state. Approximately $5 \%$ of GPP and $12 \%$ of $R$ occurred during the winter months, highlighting winter's potential role in nutrient regeneration. An overall positive annual net community production (NCP) rate of $28 \pm 6 \mathrm{mg} \mathrm{C} \mathrm{l}^{-1} \mathrm{yr}^{-1}$ makes Muskegon Lake's surface waters a net sink for carbon on an annual basis. Annual heterotrophic bacterial production (BP) rates were $5 \pm 3 \mathrm{mg} \mathrm{C} \mathrm{l}^{-1} \mathrm{yr}^{-1}$, suggesting a substantial fraction of GPP was likely processed through the microbial food web (2 to $76 \%$ ). A stepwise multiple linear regression model revealed the plausible drivers of GPP (temperature $[T]$, photosynthetically active radiation [PAR], total phosphorus [TP], dissolved oxygen [DO], chlorophyll a [chl a]), NCP (T, PAR, TP), $R$ (T, DO, ammonium $\left[\mathrm{NH}_{3}\right]$, soluble reactive phosphorous [SRP], dissolved organic carbon [DOC]) and GPP: $R(T$, PAR, SRP, DOC). Year-round measurements inform us of the strong seasonality in the carbon cycle of temperate lakes.
\end{abstract}

KEY WORDS: Lake metabolism · Primary production · Carbon · Nitrogen · Phosphorus Phytoplankton $\cdot$ Bacteria $\cdot$ Carbon balance

\section{INTRODUCTION}

Freshwater ecosystems are recognized as highly reactive sites for carbon metabolism (Cole et al. 2007, Tranvik et al. 2009). Worldwide, lakes that are at the terminus of watersheds receive substantial supplies of carbon and nutrients from terrestrial sources and have high rates of gross primary production (GPP) (Wehr et al. 1999). Because the terrestrial-aquaticatmospheric link is a key component of the global carbon cycle (Cole et al. 2007, Battin et al. 2009, Aufdenkampe et al. 2011, Borges et al. 2015), knowledge of the rates and drivers of carbon metabolism are essential aspects of ecology and biogeochemistry.

${ }^{*}$ Corresponding author: biddandb@gvsu.edu
Organic matter can be produced or destroyed through the major metabolic pathways of GPP and respiration $(R)$, and thus these are primary regulating components in the carbon flux through all aquatic ecosystems (Williamson et al. 1999, Cole et al. 2002). Therefore, researchers have focused on GPP and $R$ of plankton (where GPP $-R=$ net community production, NCP) as critical biological components in the pelagic freshwater environment (Schwaerter et al. 1988). Specific watershed characteristics determine the inputs of inorganic nutrients and organic compounds, which are then transformed by in-lake biogeochemical processes of GPP and $R$, resulting in emergent lake characteristics such as a carbon sink/ 
source status, eutrophication, harmful algal blooms and hypoxia (Hanson et al. 2003).

Studies quantifying the seasonal dynamics of freshwater metabolism and characterization of factors influencing metabolic rates and carbon flow are rare, but necessary in order to understand the carbon balance in lake ecosystems. In addition, the yearround metabolism of lakes (including the underrepresented winter season) is often overlooked. There is a severe paucity of studies in the literature that have concurrently measured both production and respiration throughout the year to assess the overall carbon balance of freshwater and marine systems globally (Karl et al. 2003, DucharmeRiel et al. 2015). Moreover, there is a common misconception that hardly any biological activity occurs during the ice-covered winter months in temperate lakes (Tulonen et al. 1994,

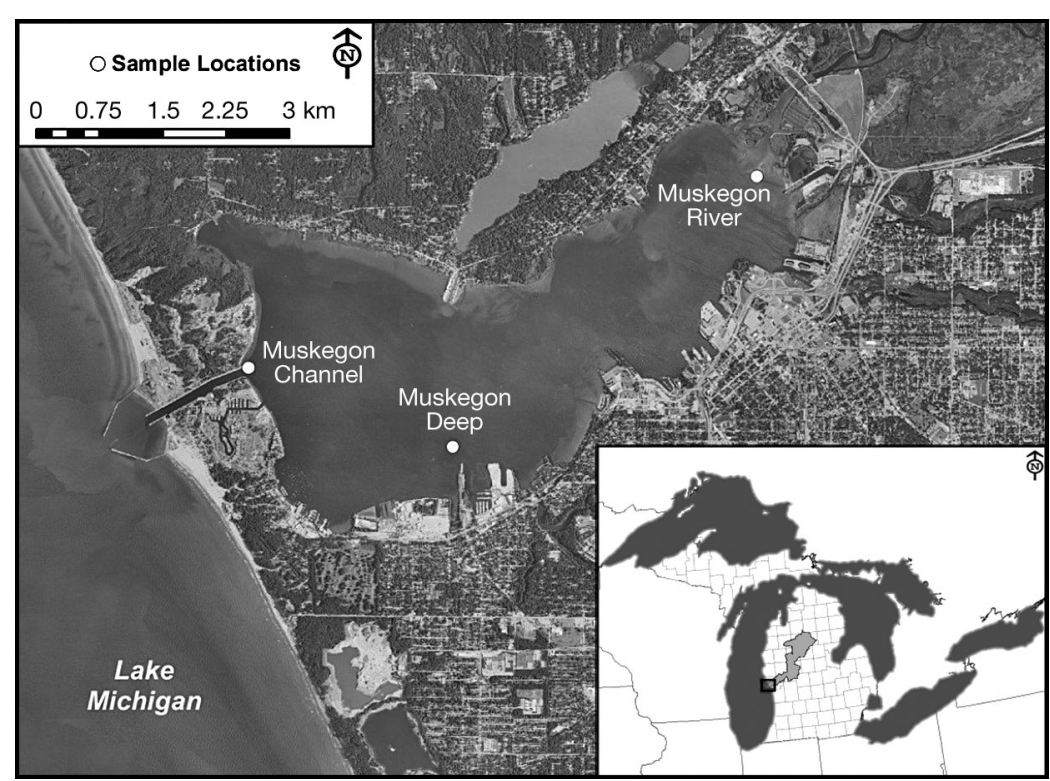

Fig. 1. Muskegon Lake study area $\left(43.2331^{\circ} \mathrm{N}, 86.2903^{\circ} \mathrm{W}\right)$ and sample locations at Muskegon River (MR), Muskegon Channel (MC) and Muskegon Deep (MD), with Lake Michigan on the left. Inset: Laurentian Great Lakes, with boxed area highlighting location of Muskegon Lake at the terminus of Muskegon River water-shed (light gray shaded region within the state of Michigan, USA)

Campbell et al. 2005, Salonen et al. 2009). Additionally, severe winter conditions restrict sampling, measurement and accessibility to research sites, contributing to the difficulties in bridging the gap in our understanding of the true metabolic balance of lake ecosystems (Salonen et al. 2009, Bertilsson et al. 2013).

The present year-round study provides the opportunity to examine organic and inorganic nutrient inventories in a dynamic freshwater ecosystem in order to determine the influence of the watershed on metabolic indices (GPP, NCP, $R$, and GPP: $R$ ), and to explore the trophic interaction between autotrophic and heterotrophic plankton on a seasonal basis to examine events and time frames in which a lake becomes a source or sink of carbon. Three earlier studies have examined the carbon cycle of Muskegon Lake, but they carried out either one singlesummer time measure or 4 discrete seasonal measurements a year, and did not perform monthly studies throughout the annual cycle (Ogdahl et al. 2010, Weinke et al. 2014, Dila \& Biddanda 2015).

The specific objectives of the present study were to (1) determine the temporal variability of planktonic metabolism through the annual cycle, (2) quantify the contribution of the cold and typically ice-covered winter season to annual metabolism, and (3) identify variables that best explain the observed variation in seasonal metabolism.

\section{MATERIALS AND METHODS}

\section{Study site}

Muskegon Lake $\left(43.2331^{\circ} \mathrm{N}, 86.2903^{\circ} \mathrm{W}\right)$ is a $17 \mathrm{~km}^{2}$ Great Lakes estuary located in the western Michigan portion of the Great Lakes basin (Fig. 1 inset; Larson et al. 2013). Based on the geomorphology and physiography scheme for estuaries, Muskegon Lake, a coastal drowned river-mouth system, is indeed a Great Lakes estuary (sensu Herdendorf 1990). Muskegon Lake is part of the larger Muskegon River watershed, which drains approximately $6822 \mathrm{~km}^{2}$, and is the second largest river in Michigan. The primary area of inflow to Muskegon Lake is the Muskegon River, entering from the east. Muskegon Lake drains directly into Lake Michigan to the west via a single outflow along a navigation channel. Most of the watershed that feeds Muskegon Lake is forested $(53.2 \%)$, with the remainder being agricultural $(23 \%)$ and urbanized (4.2\%) (Marko et al. 2013). Muskegon Lake has a water volume of $\sim 119$ million $\mathrm{m}^{3}$, a water retention time of $\sim 23 \mathrm{~d}$, and a mean water depth of $7 \mathrm{~m}$ (Carter et al. 2006, Steinman et al. 2008).

In 1985, Muskegon Lake was identified as an Area of Concern (AOC) due to severe environmental impairments from direct discharge of industrial and 
municipal waste prior to 1973, resulting in nutrient enrichment and contaminated sediments from the discharge of organic chemicals (Carter et al. 2006). Although water quality has improved (Steinman et al. 2008), changes in inorganic nutrient or organic carbon inputs from the surrounding watershed or resuspension of contaminated sediments is likely to continue to affect lake metabolism rates.

Three sampling sites were chosen based upon long-term monitoring studies (Steinman et al. 2008; our Fig. 1): Muskegon River site (MR) $\left(43.2528^{\circ} \mathrm{N}\right.$, $86.2525^{\circ} \mathrm{W}$ ), located just west of the mouth of the Muskegon River at a station depth of $6.4 \mathrm{~m}$; Muskegon Channel site (MC) $\left(43.2327^{\circ} \mathrm{N}, 86.3269^{\circ} \mathrm{W}\right)$, just east of Lake Michigan at a station depth of $12.5 \mathrm{~m}_{i}$ and Muskegon Deep site (MD) $\left(43.2240^{\circ} \mathrm{N}, 86.2972^{\circ} \mathrm{W}\right)$, which represents the deepest area of Muskegon Lake at a station depth of $20 \mathrm{~m}$ and is located just west of the Ruddiman Creek tributary.

\section{Sample collection}

Monthly surface water samples were collected with an integrated water sampler at a depth of $0.5 \mathrm{~m}$ at each of the 3 sites within Muskegon Lake during a 1 yr period from 4 February 2009 to 11 February 2010. Samples were collected in the morning between 09:00 and 11:00 h. Water samples were placed in acid-cleaned bottles and transported on ice to the Annis Water Resources Institute (Muskegon, MI) for analysis of changes in dissolved oxygen (DO), and concentrations of dissolved organic carbon (DOC), colored dissolved organic matter (CDOM), chlorophyll a (chl a), nitrate $\left(\mathrm{NO}_{3}-\mathrm{N}\right)$, ammonia $\left(\mathrm{NH}_{3}-\mathrm{N}\right)$, soluble reactive phosphorus (SRP-P), total phosphorus (TP-P), total Kjeldahl nitrogen (TKN-N), bacterial abundance (BA) and bacterial production (BP).

\section{Field measurements}

Temperature $(T), \mathrm{pH}$, conductivity, depth, DO, turbidity and photosynthetically active radiation (PAR) were measured using an YSI 6600 Datasonde calibrated according to the manufacturer's instructions (Fondriest). PAR measurements were measured using a Li-Cor quantum sensor. Initial readings of PAR were taken just above the water surface, just beneath the water surface, and at $0.5 \mathrm{~m}$ intervals until light was less than $1 \%$ of the surface value. The extinction coefficient $\left(k_{\mathrm{d}}\right)$ was estimated as the slope of the regression according to Kirk (1994).

\section{NCP, $R$, and GPP}

Changes in the concentration of DO in untreated and unfiltered water samples were measured in quadruplicate clear and darkened BOD glass bottles (300 ml). BOD bottles were filled using tubing to allow overflow for $20 \mathrm{~s}$ to ensure no air contamination, and incubated for $24 \mathrm{~h}$ in situ in Muskegon Lake suspended on a wire rack at a depth of $0.5 \mathrm{~m}$. During periods of ice cover on Muskegon Lake, a rectangle approximately $1.5 \times 0.5 \mathrm{~m}$ was cut through the ice, and BOD bottles were hung on a rack. Changes in DO between initial and final time points were measured using micro-Winkler titration with automated potentiometric endpoint detection (Carignan et al. 2000, Weinke et al. 2014).

Oxygen consumption in the darkened bottles represents community $R$, while oxygen production in the $24 \mathrm{~h}$ light bottles represents NCP. GPP was then calculated as $\mathrm{NCP}+R$ as described by Wetzel $\&$ Likens (2000). NCP simply provides a rate of biomass accumulation in the system, and GPP: $R$ ratios indicate the potential for positive or negative net primary production (NPP) in the system, with a value of 1.0 indicating perfect carbon balance. Oxygen consumed was converted to carbon respired assuming a molar respiratory quotient of 1.0 (Biddanda et al. 1994, Robinson 2008), and oxygen produced was converted to carbon produced using a molar photosynthetic quotient of 1.0 (Robinson 2008).

\section{Water chemistry}

DOC samples were filtered through $0.45 \mu \mathrm{m}$ precombusted GF/F filters (Whatman) and stored frozen in pre-combusted $20 \mathrm{ml}$ glass vials with Teflon-lined caps and used for DOC measurements after acidification and inorganic $\mathrm{C}$ removal on a Shimadzu TOC500 with a high temperature Pt catalytic oxidation. Total organic carbon standards were made from KHP, and instrument blank runs were performed with ultrapure deionized water (Biddanda \& Cotner 2002).

CDOM absorbance was determined on a Shimadzu UV-1600 visible spectrophotometer using a $5 \mathrm{~cm}$ quartz cuvette. Absorbance was then converted to an absorption coefficient at $350 \mathrm{~nm}$, in units of $\mathrm{m}^{-1}$ with the equation described in Cuthbert \& del Giorgio (1992).

Samples for $\mathrm{NO}_{3}, \mathrm{NH}_{3}$, SRP, TP and TKN were analyzed according to APHA (1998) methods 4110, 4500$\mathrm{H}$, and 4500-P. Briefly, TP, TKN, and $\mathrm{NH}_{3}$ concentrations were obtained from un-filtered $500 \mathrm{ml}$ water 
samples preserved with $\mathrm{H}_{2} \mathrm{SO}_{4}$ and stored at $4^{\circ} \mathrm{C}$. $\mathrm{NO}_{3}$ and SRP concentrations were obtained by filtering $10 \mathrm{ml}$ aliquots through $0.45 \mu \mathrm{m}$ acid-rinsed Millipore membrane filters, and were stored at $-10^{\circ} \mathrm{C}$. All samples were prepared within $8 \mathrm{~h}$, and analyzed within $28 \mathrm{~d}$ of collection.

\section{Phytoplankton analyses}

Algal biomass was estimated as chl a. Chl a was collected by filtering lake water through $0.47 \mu \mathrm{m}$ Whatman GF/F filters; samples were immediately frozen at $-10^{\circ} \mathrm{C}$ until analysis, followed by acetone extraction for $24 \mathrm{~h}$. Fluorescence was determined using a Shimadzu UV-1600 visible spectrophotometer (Bot \& Colijn 1996).

\section{Bacterioplankton analyses}

Heterotrophic bacteria were preserved with $2 \%$ formalin, stained with Acridine Orange, and filtered onto black $25 \mathrm{~mm}$ polycarbonate Millipore filters (0.2 $\mu \mathrm{m}$ pore size) for enumeration. Slides were stored frozen until enumeration by standard epifluorescent microscopy at 1000× magnification according to Hobbie et al. (1977). BP was measured by means of $\left[{ }^{3} \mathrm{H}\right]$ leucine incorporation into protein in the dark as described by Simon \& Azam (1989). To estimate the contribution of bacteria to planktonic GPP and thus the flow of carbon through bacteria, we calculated ratios of BP:GPP according to Findlay et al. (1992) and assumed a conservative bacterial growth efficiency of $50 \%$ (Biddanda et al. 2001, del Giorgio \& Williams 2005).

\section{Data analysis}

Metabolism measurements based on changes in DO within light and dark bottle incubations that were made during the first sampling month in February 2009 were seriously compromised both by warming during bottle filling in the laboratory before incubation, and by the loss of multiple replicate bottles due to breakage upon retrieval in sub-zero air temperatures. Therefore, we excluded the metabolism data from the February 2009 sampling date. However, all other associated data for
February 2009 were included in this study. Thus, the reported values of averages and means for metabolism refer to data from March 2009 to February 2010, whereas for all other variables the data are from February 2009 to February 2010. Unless otherwise stated, values are presented as means $\pm \mathrm{SE}$.

Statistical analyses were performed using SPSS (PASW) 18.0. A paired repeated measure 2-way ANOVA was used to detect differences in physical, chemical and biological factors among sites and seasons. Stepwise multiple linear regressions were used to test for relationships between metabolic rates of GPP, NCP, $R$ and physical ( $T$, Secchi depth, DO, Irradiance-PAR), chemical (DOC, CDOM, $\mathrm{NO}_{3}-\mathrm{N}, \mathrm{NH}_{3}$, $\mathrm{SRP}, \mathrm{TP}$ and TKN) and biological (chl a, BA, BP) variables. Results of statistical tests were considered significant at $p<0.05$. For the purpose of discussion, we divided the study year into 4 seasons: winter (December, January, February), Spring (March, April, May), summer (June, July, August) and fall (September, October, November). Winter encompassed the period when the lake was covered by ice, spring encompassed the period of ice-out to the beginning of stratification, summer encompassed the stratified period and fall encompassed the end of stratification to the beginning of ice cover.

\section{RESULTS}

Physical, chemical and biological factors influencing aquatic metabolism from 4 February 2009 to 11 February 2010 were evaluated between seasons and sites using a univariate analysis of variance (paired 2-way repeated measure ANOVA; Table 1). Signifi-

Table 1. Repeated measure ANOVA results for chemical, physical and biological factors among seasons for Muskegon Lake; results were considered significant at $\alpha=0.05$; no significant differences were found among sites

\begin{tabular}{|c|c|c|}
\hline Factor & Source & p-value \\
\hline Temperature $\left({ }^{\circ} \mathrm{C}\right)$ & Season & $<0.001$ \\
\hline Dissolved oxygen $\left(\mathrm{mg} \mathrm{l}^{-1}\right)$ & Season & $<0.001$ \\
\hline Photosynthetically active radiation $\left(\mu \mathrm{mol} \mathrm{m} \mathrm{m}^{-2} \mathrm{~s}^{-1}\right)$ & Season & 0.008 \\
\hline Light extinction coefficient (m) & Season & 0.001 \\
\hline Chlorophyll a $\left(\mu \mathrm{g} \mathrm{l}^{-1}\right)$ & Season & $<0.001$ \\
\hline Bacterial abundance $\left(\right.$ cells l$\left.^{-1}\right)$ & Season & 0.002 \\
\hline Bacterial production $\left(\mu \mathrm{g} \mathrm{C} \mathrm{l}^{-1} \mathrm{~d}^{-1}\right)$ & Season & 0.013 \\
\hline Nitrate $\left(\mu \mathrm{gl}^{-1}\right)$ & Season & $<0.001$ \\
\hline Dissolved organic carbon $\left(\mathrm{mg} \mathrm{l}^{-1}\right)$ & Season & 0.003 \\
\hline Colored dissolved organic matter $\left(a_{350 \mathrm{~nm},} \mathrm{~m}^{-1}\right)$ & Season & 0.05 \\
\hline 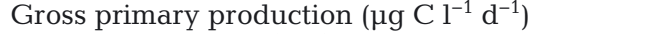 & Season & 0.0013 \\
\hline Respiration $\left(\mu \mathrm{g} \mathrm{C} \mathrm{l}^{-1} \mathrm{~d}^{-1}\right)$ & Season & $<0.001$ \\
\hline Net primary production $\left(\mu \mathrm{g} \mathrm{C} \mathrm{l}^{-1} \mathrm{~d}^{-1}\right)$ & Season & 0.006 \\
\hline
\end{tabular}


cant interactions were found between seasons for 13 of the 22 factors. Considering there were no significant differences between sites, site variation was not illustrated in the figures; instead, site values $(\mathrm{n}=3)$ for each sampling date were averaged for each factor and then illustrated in the figures.

\section{Physical parameters}

Ice formed on the lake in late November 2008, with permanent ice cover occurring by mid-December and persisting until late March 2009. Ice thickness was approximately $0.50 \mathrm{~m}$ on the first sampling event in February 2009. Ice formed again on the lake in early December 2009, with permanent cover by late December that lasted until mid-March 2010 with ice thickness only reaching $0.2 \mathrm{~m}$.

The temperature of the surface water ranged from a minimum of $0.05 \pm 0.01^{\circ} \mathrm{C}$ in February 2009 to a maximum of $23.67 \pm 0.33^{\circ} \mathrm{C}$ in July (Fig. 2A). Rapid temperature changes with depth in excess of $0.5^{\circ} \mathrm{C}$ indicated that thermal stratification began in midJune when surface temperatures exceeded $\sim 17^{\circ} \mathrm{C}$ and continued until fall turnover around the second week of October when temperatures fell to $\sim 11^{\circ} \mathrm{C}$; the thermocline was located at approximately $7 \mathrm{~m}$ depth.

DO concentrations in surface waters ranged from a minimum of $8.14 \pm 0.26 \mathrm{mg} \mathrm{l}^{-1}$ in August to a maxi- mum of $13.20 \pm 0.15 \mathrm{mg} \mathrm{l}^{-1}$ in December (Fig. 2D). While no low or anoxic conditions occurred at Site MR, Sites MD and MC did experience low oxygen conditions. During summer stratification, DO concentrations at Site MD ranged from $10.29 \mathrm{mg} \mathrm{l}^{-1}$ at the surface to $4.81 \mathrm{mg} \mathrm{l}^{-1}$ at $11 \mathrm{~m}$ depth in July, and $8.40 \mathrm{mg} \mathrm{l}^{-1}$ at the surface to $5.10 \mathrm{mg} \mathrm{l}^{-1}$ at $9.5 \mathrm{~m}$ in August. Similar concentrations were observed at Site $\mathrm{MC}$ in July, ranging from $9.82 \mathrm{mg} \mathrm{l}^{-1}$ at the surface to $4.76 \mathrm{mg} \mathrm{l}^{-1}$ at $8 \mathrm{~m}$.

PAR ranged from a maximum of $2432 \pm 67 \mu \mathrm{mol}$ $\mathrm{m}^{-2} \mathrm{~s}^{-1}$ in August to a minimum of $141 \pm 1 \mu \mathrm{mol} \mathrm{m} \mathrm{m}^{-2}$ $\mathrm{s}^{-1}$ in October (Fig. 2C). National Weather Service archived satellite data confirmed cloud cover on the October 2009 sampling date, along with other lowPAR days. The underwater light climate also exhibited a seasonal pattern, with the maximum $k_{\mathrm{d}}$ observed in March $(2.16 \pm 0.45 \mathrm{~m})$ and the minimum in October $(0.70 \pm 0.0 \mathrm{~m})$.

Cumulative daily discharge values, as measured by the US Geological Survey gauge at Croton, MI, revealed that the lowest average monthly discharge value $\left(32 \mathrm{~m}^{-3} \mathrm{~s}^{-1}\right)$ was recorded in September; the highest value $\left(120 \mathrm{~m}^{-3} \mathrm{~s}^{-1}\right)$ was recorded in March. Discharge values in March and May are most likely the result of snowmelt and rainfall. The increase in discharge did not always directly correspond to an increase in daily precipitation (see Tables S1 \& S2 in the Supplement at www.int-res.com/articles/suppl/ a077p139_supp.pdf).
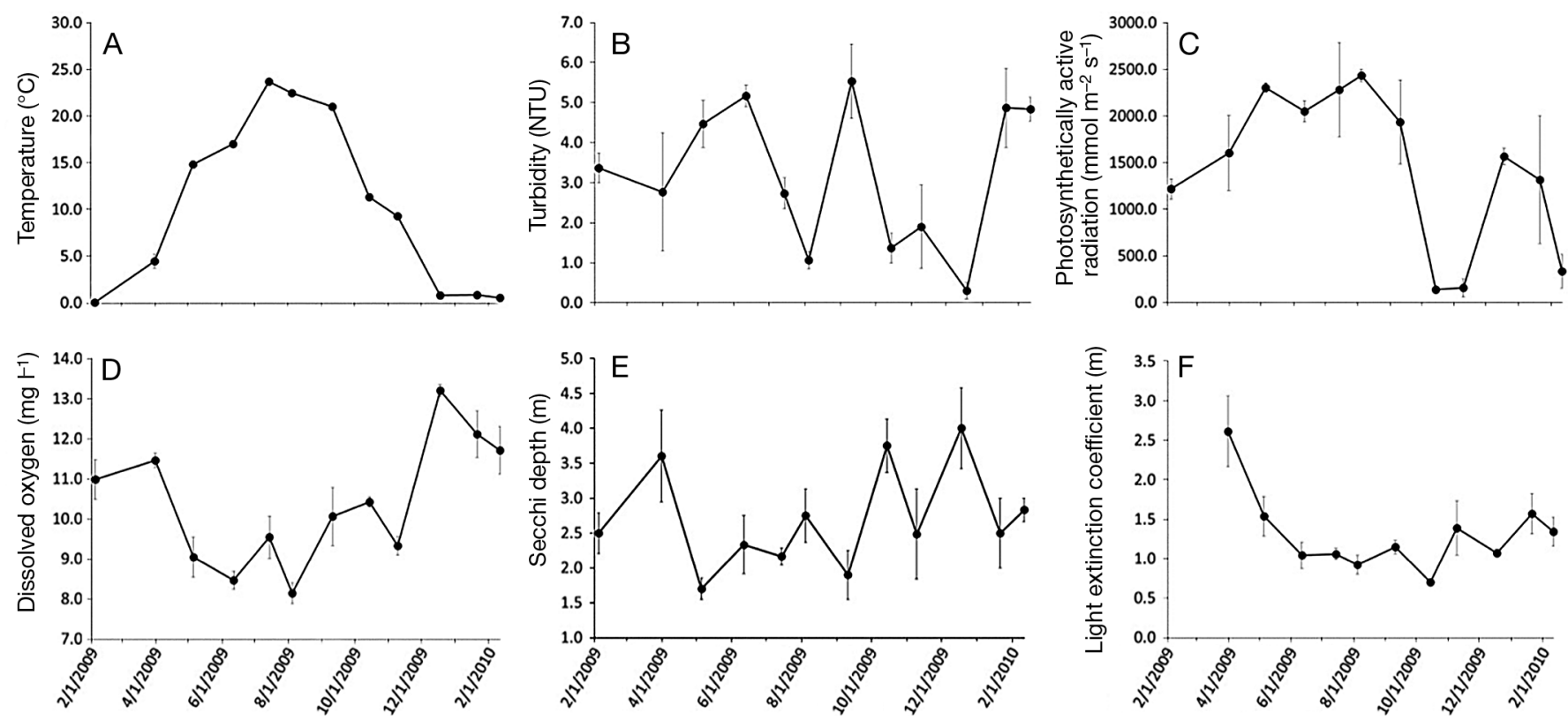

Fig. 2. Site-averaged (A) surface water temperature, (B) turbidity, (C) photosynthetically active radiation, (D) dissolved oxygen, (E) Secchi disk depth and (F) light extinction coefficient in Muskegon Lake between 4 February 2009 and 11 February 2010. Error bars: $\pm 1 \mathrm{SE}_{\text {; }}$ dates are presented as $\mathrm{mo} / \mathrm{d} / \mathrm{yr}$ 


\section{Nutrients}

High concentrations of SRP, TP, $\mathrm{NH}_{3}$ and TKN were recorded at all sites during February 2010, and the riverine site MR recorded markedly higher concentrations (Fig. 3). It is important to note that $10 \mathrm{~mm}$ of rain and $177 \mathrm{~mm}$ of snow were recorded less than $48 \mathrm{~h}$ prior to the 11 February 2010 sampling event, and the increased concentrations may reflect recent river loading. TKN declined sharply in October, coinciding with fall turnover. Similar to TP, TKN showed a particularly high concentration of $930 \mu \mathrm{g} \mathrm{l}^{-1}$ at Site MR in February 2010.
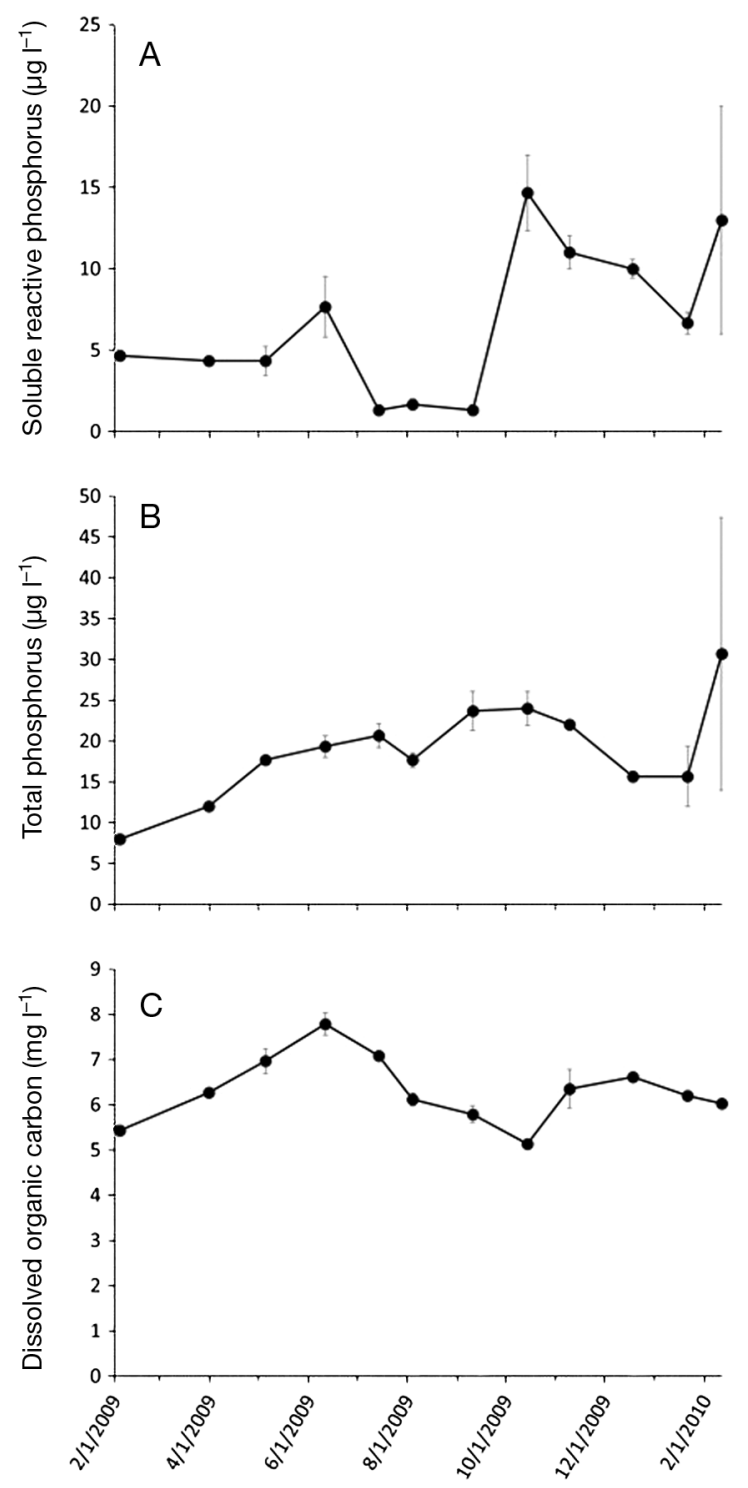

SRP exhibited a summer drawdown from July to September, achieving an average monthly maximum concentration of $14.67 \pm 2.33 \mu \mathrm{g} \mathrm{l}^{-1}$ in October 2009, coinciding with fall turnover. With the exception of the particularly high reading at Site MR in February 2010, $\mathrm{NH}_{3}$ remained relatively constant throughout the entire study, averaging $55.14 \pm 11.80 \mu \mathrm{g} \mathrm{l}^{-1}$ with no apparent seasonal pattern.

The average DOC concentration was $6.32 \pm 0.13$ $\mathrm{mg} \mathrm{l}^{-1}$ and the average CDOM absorption coefficient $\left(a_{350 \mathrm{~nm}}\right)$ was $2.26 \pm 0.16 \mathrm{~m}^{-1}$. Both DOC and CDOM showed the same 2 distinct peaks during the study period (Fig. 3C,F), with maximum values
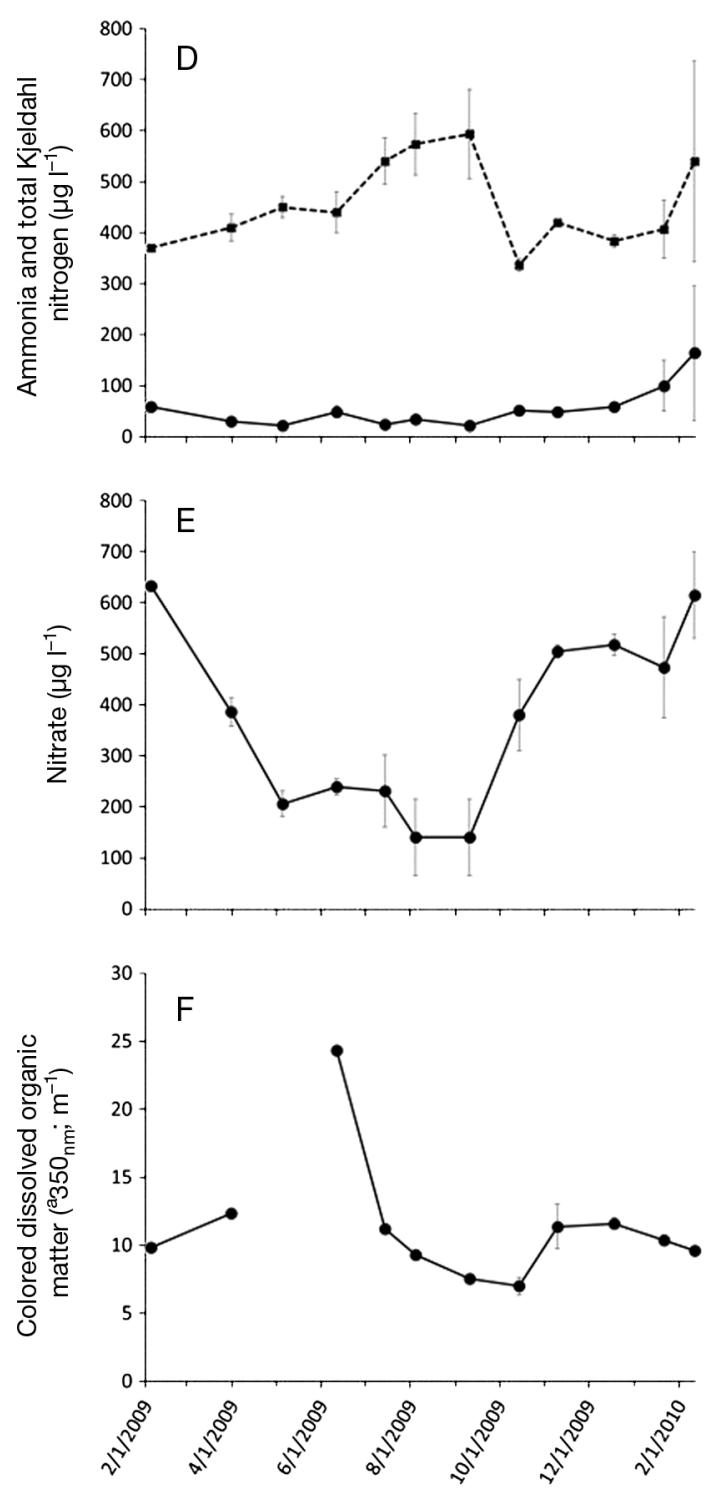

Fig. 3. Site-averaged temporal variation in concentrations of (A) soluble reactive phosphorus, (B) total phosphorus, (C) dissolved organic carbon, (D) ammonia and total Kjeldahl nitrogen (solid and dashed lines, respectively), (E) nitrate and (F) colored dissolved organic matter from Muskegon Lake from 4 February 2009 to 11 February 2010. Colored dissolved organic matter was not measured in May. Error bars: $\pm 1 \mathrm{SE}_{\text {; }}$ dates are presented as mo/d/yr 


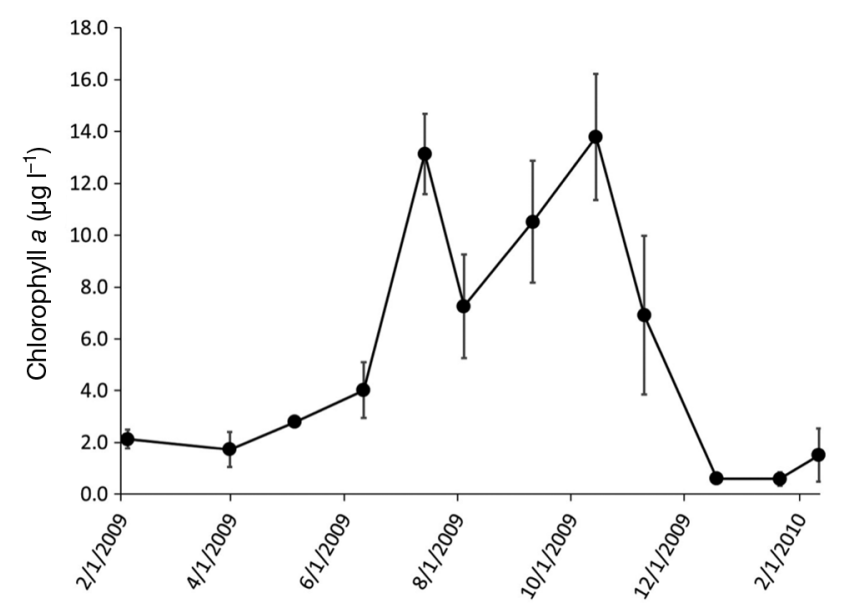

Fig. 4. Site-averaged chl $a$ in the water column from Muskegon Lake from 4 February 2009 to 11 February 2010. Error bars: $\pm 1 \mathrm{SE}$; dates are presented as $\mathrm{mo} / \mathrm{d} / \mathrm{yr}$ observed in June and December and minimum values observed in February 2009 and October 2009.

\section{Phytoplankton}

Phytoplankton biomass (as indicated by chl a) exhibited a seasonal pattern (Fig. 4). The seasonal minimum was observed in January 2010 (0.59 \pm 0.25 $\mu g \mathrm{l}^{-1}$ ). A peak of $13.14 \pm 1.55 \mu \mathrm{g} \mathrm{l}^{-1}$ was observed in July and corresponded with the maximum surface water temperature and an increase in GPP (Fig. 5A). The second peak in October of $13.79 \pm 2.43 \mu \mathrm{g} \mathrm{l}^{-1}$ corresponded with fall turnover of the lake, but did not correspond to an increase in surface water temperature or GPP.
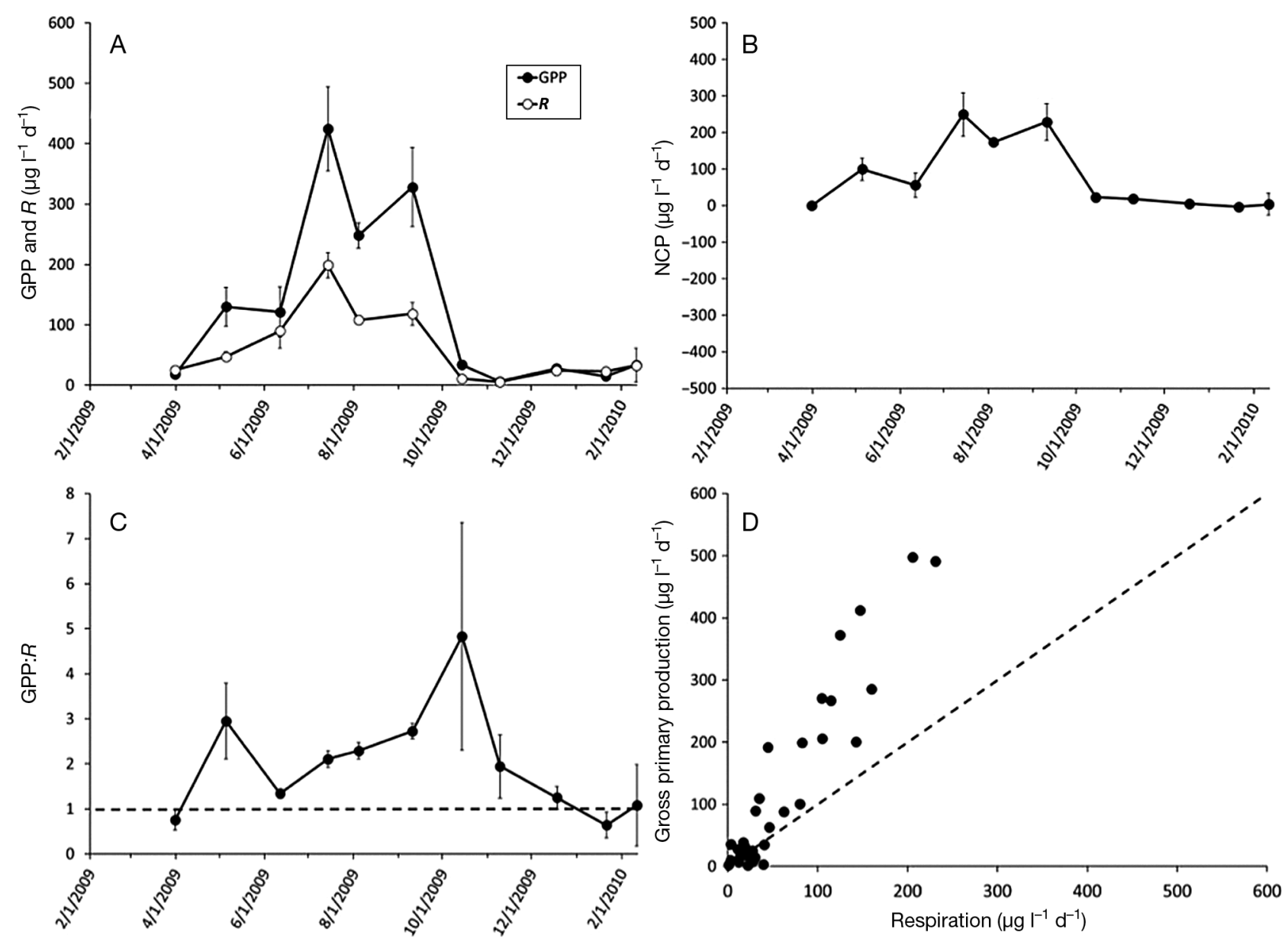

Fig. 5. Site-averaged (A) gross primary production (GPP, closed circles) and community respiration $(R$, open circles), (B) net community production (NCP), (C) ratio of gross primary production/community respiration (GPP: $R$ ) and (D) correlation between GPP and $R$ from Muskegon Lake between 4 February 2009 and 11 February 2010. Overall positive NCP values (B) and GPP: $R$ values above the dashed line (C) indicate time frames where Muskegon Lake is a sink of carbon. Values above dashed line (at 1:1 ratio of GPP:R) represent net autotrophy and values below dashed line represent net heterotrophy in Muskegon Lake $(\mathrm{C}, \mathrm{D})$. Error bars: $\pm 1 \mathrm{SE}$; dates are presented as mo/d/yr 


\section{Planktonic metabolism}

Metabolic rates of GPP, NCP and $R$ exhibited marked seasonal patterns. Rates of GPP ranged from $6.4 \pm 2.0 \mu \mathrm{g} \mathrm{C} \mathrm{l}^{-1} \mathrm{~d}^{-1}$ in November 2009 to $424.7 \pm$ $69.5 \mu \mathrm{g} \mathrm{C}^{-1} \mathrm{~d}^{-1}$ in July, with an average of $126.0 \pm$

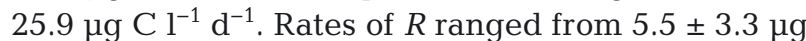
$\mathrm{C}^{-1} \mathrm{~d}^{-1}$ in November to $198.8 \pm 20.8 \mu \mathrm{g} \mathrm{C} \mathrm{l}^{-1} \mathrm{~d}^{-1}$ in July 2009, with an average of $62.2 \pm 10.6 \mu \mathrm{g} \mathrm{C}^{-1} \mathrm{~d}^{-1}$ (Fig. 5A). In general, $R$ followed the same trend as GPP, albeit with lower rates.

\section{Search for drivers of GPP, $R$, NCP and GPP:R}

Stepwise multiple linear regressions models identified the predictor variables for GPP, $R, \mathrm{NCP}$ and the GPP: $R$ ratio (Table 2). Log-transformed GPP rates revealed a significant $(\mathrm{p}<0.001)$ positive relationship with $T, \mathrm{DO}, \mathrm{PAR}, \mathrm{TP}$ and chl a (overall model $\mathrm{R}^{2}=$ 0.91). A similar analysis of $R$ rates showed a significant positive relationship with $T, \mathrm{DO}, \mathrm{NH}_{3}, \mathrm{SRP}$ and DOC (overall model $\mathrm{R}^{2}=0.75$ ). The metabolic balance of NCP revealed a significant positive relationship with $T$, PAR and TP (overall model $\mathrm{R}^{2}=0.73$ ). The GPP: $R$ ratio revealed a significant positive rela-

Table 2. Stepwise multiple linear regression models for gross primary production (GPP), net community production (NCP), respiration $(R)$, and the GPP: $R$ ratio. Predictors were considered significant at $\alpha=0.05$. Data were log transformed for GPP, NCP, $R$ and GPP: $R$. DO: dissolved oxygen; PAR: photosynthetically active radiation; TP: total phosphorus; SRP: soluble reactive phosphorus; DOC: dissolved organic carbon

\begin{tabular}{|lccccl|}
\hline $\begin{array}{l}\text { Dependent } \\
\text { variable }\end{array}$ & $\begin{array}{c}\text { Para- } \\
\text { meter }\end{array}$ & $\begin{array}{c}\text { Overall } \\
\mathrm{R}^{2}\end{array}$ & $\begin{array}{c}\text { Coeffi- } \\
\text { cient }\end{array}$ & $t$ & p-value \\
\hline GPP & Temp. & 0.9058 & 0.198 & 5.823 & $<0.001$ \\
$\mathrm{n}=33$ & DO & & 0.379 & 3.414 & $<0.01$ \\
& PAR & & 0.001 & 3.353 & $<0.01$ \\
& TP & & 0.069 & 6.379 & $<0.001$ \\
& Chl $a$ & & -0.071 & -2.246 & $<0.05$ \\
& Temp. & 0.7478 & 0.102 & 4.148 & $<0.001$ \\
$R$ & DO & & 0.267 & 2.608 & $<0.05$ \\
$\mathrm{n}=33$ & NH 3 & & 9.544 & 4.546 & $<0.001$ \\
& SRP & & -0.150 & -4.783 & $<0.001$ \\
& DOC & & 0.456 & 2.871 & $<0.01$ \\
NCP & Temp. & 0.7341 & 0.074 & 4.62 & $<0.001$ \\
$\mathrm{n}=33$ & PAR & & 0.001 & 3.164 & $<0.01$ \\
& TP & & 0.049 & 3.686 & $<0.01$ \\
GPP: $R$ & Temp. & 0.674 & 0.086 & 5.61 & $<0.001$ \\
$\mathrm{n}=33$ & PAR & & 0.001 & 3.619 & $<0.01$ \\
& SRP & & 0.145 & 5.644 & $<0.001$ \\
& DOC & & -0.466 & -2.645 & $<0.05$ \\
& & & & & \\
\hline
\end{tabular}

tionship with $T$, PAR, SRP and DOC (overall model $\mathrm{R}^{2}=0.67$ ).

\section{Bacterioplankton}

BA and BP followed a similar seasonal trend over the study duration (Fig. 6). However, minimum values for BA were observed in January $2010\left(8.5 \times 10^{7}\right.$ $\pm 1.2 \times 10^{7}$ cells $1^{-1}$ ), while minimum values for BP were observed in February $2009\left(1.68 \pm 0.11 \mu \mathrm{g} \mathrm{C}^{-1}\right.$ $\mathrm{d}^{-1}$ ). Over the seasons, BP constituted a conservative estimate of between 1 and $36 \%$ of the GPP (Fig. 6). Based on measured BP and a comparable rate of bacterial respiration (BR), assuming a conservative bacterial growth efficiency (BGE) of $50 \%$ (del Giorgio et al. 1997, Biddanda et al. 2001) suggests that the total carbon flux through bacteria (CFTB) may be between 2 and $76 \%$ of GPP.

\section{GPP: $R$ ratio}

The GPP: $R$ ratio exhibited marked seasonality (Fig. 5C). Plankton metabolism was annually autotrophic (mean GPP: $R$ ratio of $2.0 \pm 0.3$ ), with sustained autotrophy throughout the year. The maximum site-averaged GPP: $R$ ratio of $4.8 \pm 2.5$ occurred in October and coincided with fall turnover. A particularly high GPP: $R$ ratio of 9.86 occurred at Site MC in October 2010, which resulted from a particularly low $R$ rate compared to Sites MR and MD, while the site's GPP rate was similar to that of MR and MD.

\section{DISCUSSION}

\section{Variable GPP, $R$, NCP and GPP: $R$ with net annual autotrophy}

The primary objective of this study was to determine the temporal variability of planktonic metabolism in a Great Lakes estuary. Although several studies have reported large temporal variability within ecosystems (Smith \& Hollibaugh 1997, Cole et al. 2000, Staehr \& Sand-Jensen 2007, Ogdahl et al. 2010), the temporal variability of GPP, NCP, $R$ and the GPP: $R$ ratio was much more pronounced in the present study than has been previously measured in the few available year-round estimates of lake metabolism. In addition to the pronounced seasonality prevalent throughout the annual cycle, the intense hydrodynamics of this system-a drowned river- 
mouth estuary - may also be partly responsible for this pronounced seasonality.

On the basis of the monthly measurements we were able to estimate the contribution of each season to yearly GPP, NCP and $R$ metabolic rates (Fig. 7).
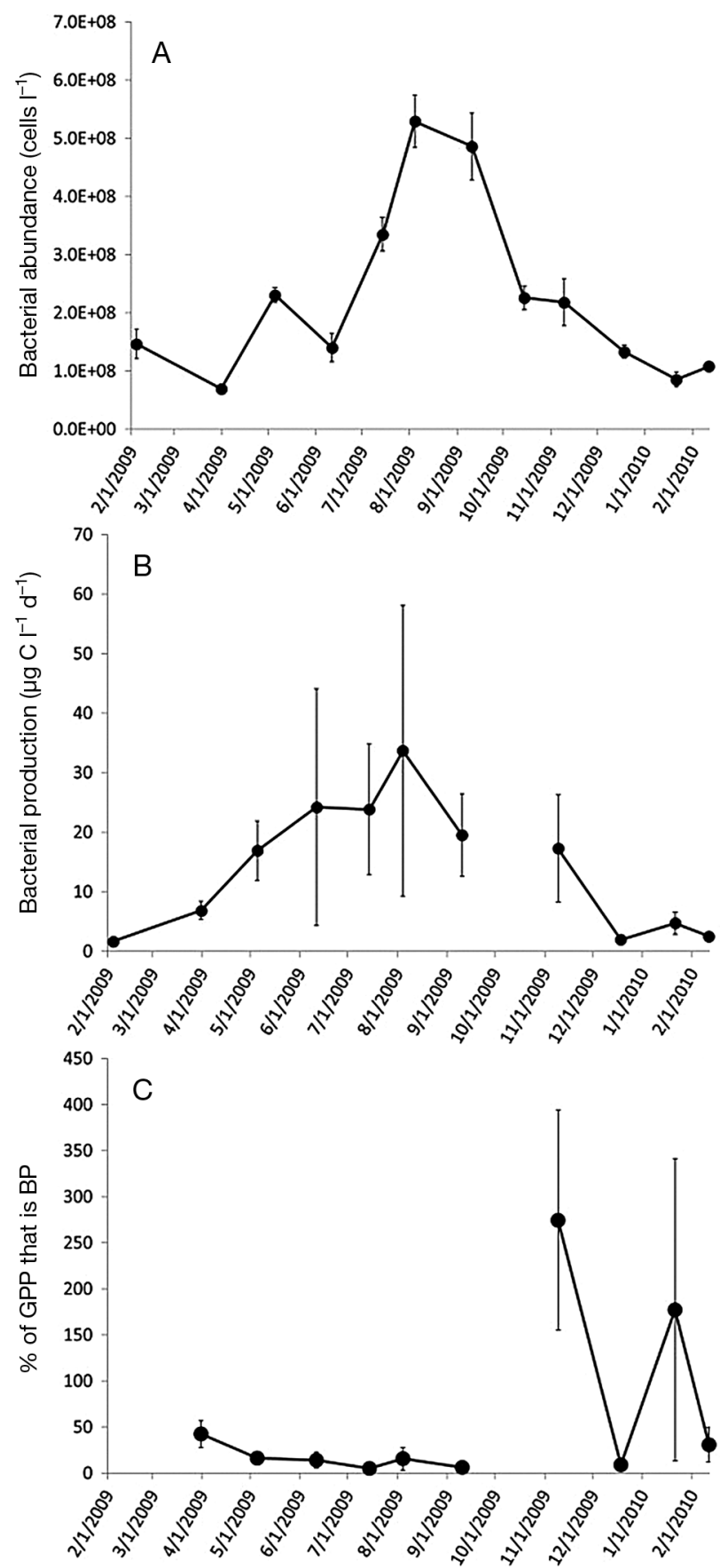

Fig. 6. Site-averaged (A) bacterial abundance, (B) bacterial production and $(\mathrm{C})$ percent of gross primary production (GPP) that is bacterial production (BP) in Muskegon Lake from 4 February 2009 to 11 February 2010. Bacterial production data are not available for October 2009. Error bars: $\pm 1 \mathrm{SE}_{;}$dates are presented as mo/d/yr
The underrepresented winter season (December, January and February) contributed $6 \pm 2.6 \%$ to the yearly GPP, $12 \pm 0.3 \%$ to the yearly $R$, and $1 \pm 3.9 \%$ of the yearly NCP. Although metabolic activity was relatively low in winter, this period could be important for the annual carbon balance of lakes in high latitude regions subject to long winters by way of respiration-driven nutrient regeneration (Welch \& Bergmann 1985, Bertilsson et al. 2013, Ducharme-Riel et al. 2015) (Fig. 8).

Metabolic balance is often represented as a ratio of GPP: $R$ and is a useful index for assessing the relative autotrophic versus heterotrophic status of ecosystems (Odum 1956,1957, del Giorgio \& Peters 1994, Kemp et al. 1997, Cole et al. 2000, Hanson et al. 2003). Planktonic GPP: $R$ ratios clearly indicate that Muskegon Lake is autotrophic during the summer months into the late fall, and most surprisingly, into the early winter under ice cover; comparable results where $R$ was relatively higher than GPP were reported during December by Dila \& Biddanda (2015). In the present study, GPP: $R$ was highest during the summer/fall period and lowest during winter. Similarly, DucharmeRiel et al. (2015) found the highest carbon uptake in surface waters and higher volumetric accumulation of $\mathrm{CO}_{2}$ in the hypolimnion in the summer than during the winter. They determined that the predicted correlation with temperature was not significant. This again points to other drivers in the carbon cycle, such as mixing and/or an increased role of BR during summer. Whereas all the parameters identified in Table 2 (such as T, PAR and TP) are possible predictors of metabolism, not all of them (such as DO) that are both a product and substrate of metabolism, serve as actual drivers.

\section{Seasonal cycle of inorganic nutrients and organic matter in a temperate lake}

During the summer, dissolved inorganic nutrients are depleted from the photic zone (Elser et al. 2009). The summer declines in SRP and $\mathrm{NO}_{3}-\mathrm{N}$ are consistent with phytoplankton growth, as evidenced by increasing chl a concentrations (Weinke et al. 2014). Reduced SRP and $\mathrm{NO}_{3}-\mathrm{N}$ in the spring, with low levels continuing throughout summer have been attributed to the rapid assimilation of biologically available $\mathrm{P}$ and $\mathrm{NO}_{3}-\mathrm{N}$ by algae throughout spring and summer, when increased light levels and temperatures favor growth (Bennion \& Smith 2000). This suggests that available $\mathrm{P}$ is more rapidly incorporated into the biotic pool during the summer (Porter et al. 1996) 

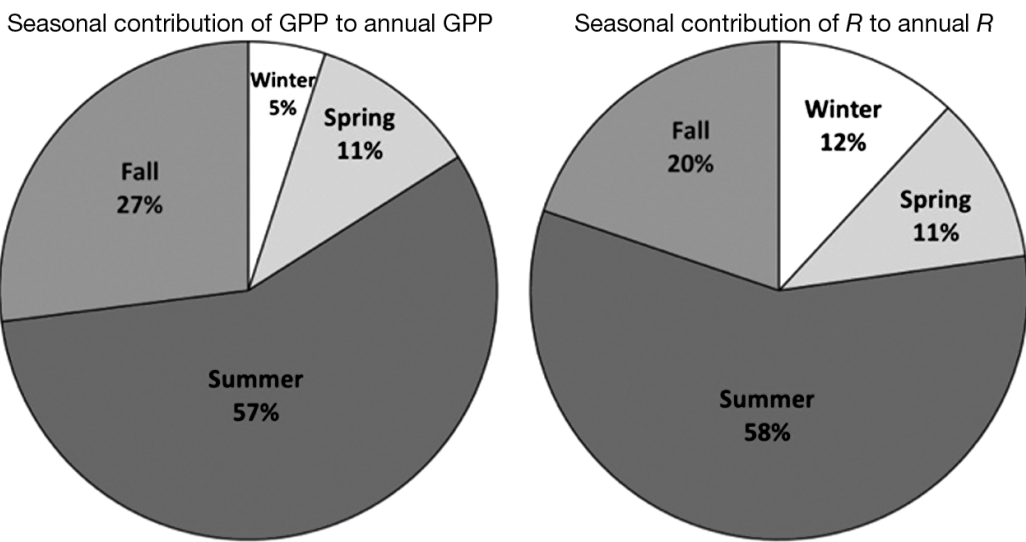

Seasonal contribution of NCP to annual NCP
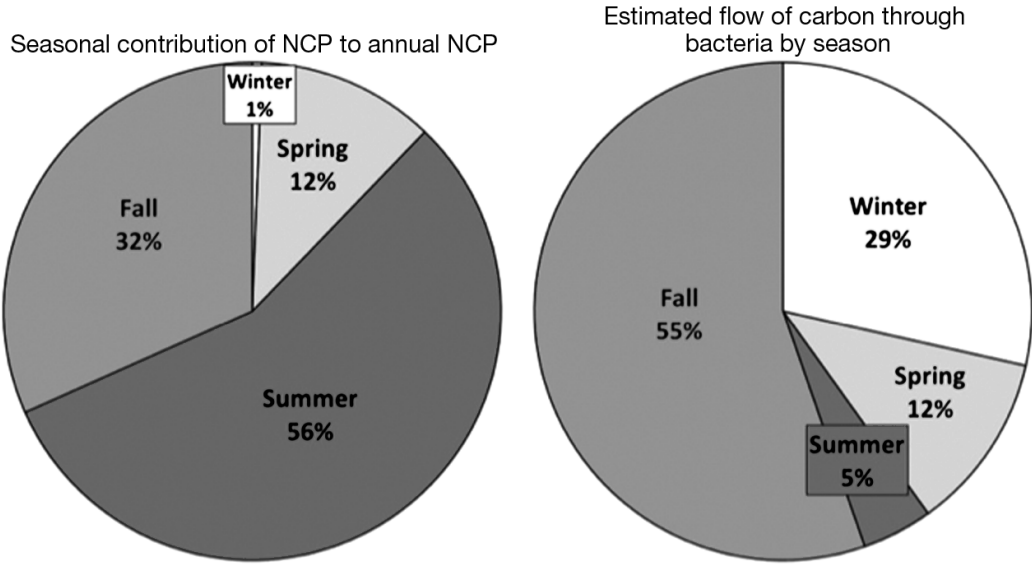

Fig. 7. Seasonal contribution of spring, summer, fall and winter to annual gross primary production (GPP), respiration $(R)$ and net community production $(\mathrm{NCP})$, and the flow of carbon through heterotrophic bacterioplankton by season in Muskegon Lake from 4 February 2009 to 11 February 2010

major role at this time, since inputs of DOM have been reported to stimulate $R$ leading to net heterotrophy (del Giorgio \& Peters 1994), which was not observed during the late fall/early winter time frame. Muskegon Lake is dystrophic, and productivity is likely limited by color (Beisner et al. 2003). Additionally, an explanation of the higher GPP: $R$ ratio is the recalcitrant nature of DOM from the upstream wetland complex, and recalcitrant DOM has been reported to significantly increase bacterial respiration leading to a reduction in GPP: $R$ ratios (Staehr \& Sand-Jensen 2007).

Further, the residence time of Muskegon Lake is $23 \mathrm{~d}$ (Carter et al. 2006). Navarro et al. (2004) suggests that in a system with such short residence times, a large seasonal storage of nutrients in the water column seems unlikely. Given that Muskegon Lake receives $95 \%$ of its tributary input from the Muskegon River, it seems likely that any observed increase in nutrients in the lake is a reflection of loading from the river (Carter et al. 2006). Observed GPP: $R$ ratios $>1$ in late fall/early winter further lend support to the notion that the surrounding extensive watershed plays a vital biogeochemical

than during the late fall/early winter (as $\mathrm{NH}_{3}$, SRP and $\mathrm{NO}_{3}-\mathrm{N}$ ), when uptake by phytoplankton is minimal (Bennion \& Smith 2000). This is in line with the findings of Dila \& Biddanda (2015), who found that May, July and September all showed increased levels of autotrophic biomass and activity, which corresponded with decreased levels of available reduced nitrogen sources $\left(\mathrm{NO}_{3}\right.$ and $\left.\mathrm{NH}_{4}\right)$. Furthermore, the drowned river-mouth Muskegon Lake estuary is a net retainer of nutrients in the watershed, which may have a profound effect on GPP (Marko et al. 2013).

The geomorphology and biology of Muskegon Lake conspire to intercept upland nutrients (e.g. $\mathrm{NO}_{3}-\mathrm{N}$ and SRP) before they plume out into Lake Michigan, explaining the high NPP observed in this system (Mitsch et al. 2005). Further, nutrient retention typically increases over the growing season as macrophyte cover increases (Mitsch et al. 2005). DOC and CDOM values for late fall/early winter were similar to those observed in mid- to late summer. It is unlikely that the inputs of DOC and CDOM played a role in the Muskegon Lake ecosystem. Factors such as soils, geology, topography, vegetation, land use and land cover can have a significant impact on water chemistry (Gergel et al. 1999), and watershed characteristics determine the inputs of carbon and nutrients into receiving basins such as lakes (Dillon \& Molot 1997). Although the upper regions of the watershed are largely forested, the lower watershed of Muskegon River is a mix of urban and agriculture - and this mix of land use may impact the nature of loading.

\section{Role of phytoplankton and bacterioplankton in the lake's carbon cycle}

In the present study, phytoplankton biomass (as indicated by chl a) peaked first in July and then again in October. A large spring phytoplankton bloom followed by a smaller autumn bloom is consistent with phytoplankton dynamics in lakes (Sommer et al. 1986). A significant correlation between GPP and BP 


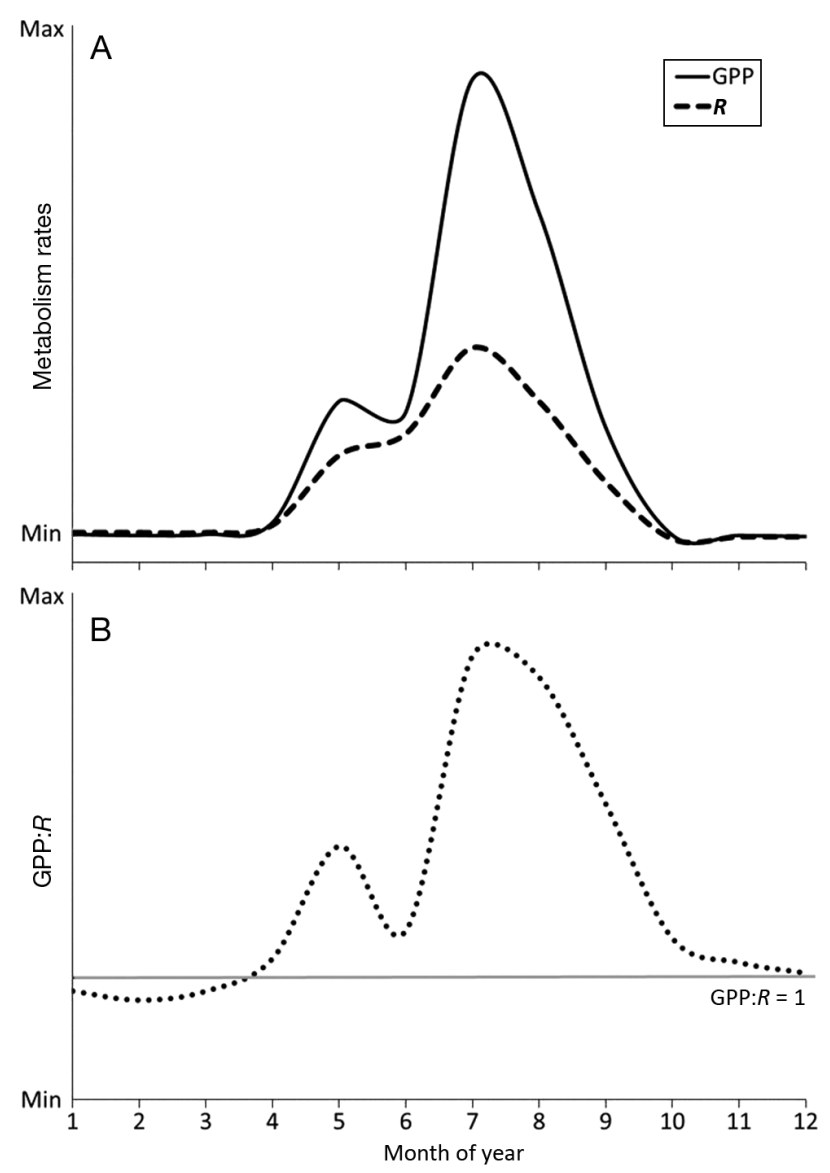

Fig. 8. Conceptual diagram of trends in (A) the seasonal metabolism (gross primary production, GPP and respiration, $R$ ) and (B) carbon represented as the ratio of GPP: $R$. The 1:1 line indicates the zone of carbon balance above which net production (autotrophy) prevails and below which net respiration (heterotrophy) prevails. Note: data from Fig. 5 was smoothed to obtain these general trends

is indicative of a close coupling between autotrophic phytoplankton and heterotrophic bacteria in the ecosystem.

Furthermore, the significant relationships between GPP, BP, BA and chl a suggest that phytoplankton or material produced by phytoplankton are important substrates for bacterial growth (Cole et al. 1988). In fact, BP amounted to anywhere from 1 to $36 \%$ of GPP, suggesting that the total CFTB could be between 2 and $76 \%$ in Muskegon Lake. The trend of a high flux of GPP into BP was pronounced in the fall season, but continued into the winter season as well (Fig. 7). This estimate assumes a conservative BGE of $50 \%$, and since BGEs are typically in the range of 20 to $30 \%$ for water bodies such as Muskegon Lake, the actual consumption of carbon by Muskegon Lake bacteria may be even higher (Biddanda et al. 2001, del Giorgio \& Williams 2005).
In addition to the positive correlation between GPP and $\mathrm{BA}$, other studies have also reported a positive correlation between GPP and BP, indicating an even closer coupling than observed in Muskegon Lake (Cole et al. 1988, Ducklow \& Carlson 1992, Biddanda et al. 1994). Moreover, according to Liu et al. (2011) the significant correlation between GPP and $R$ (e.g. Fig. 5D) reflects the importance of autochthonous production in supplying organic matter to sustain heterotrophic activity. Thus, productive land-margin ecosystems may be well positioned to optimize the use of both autochthonous and allochthonous inputs.

Our estimates - based on measured BP and a comparable rate of $\mathrm{BR}$, and assuming a conservative $\mathrm{BGE}$ of $50 \%$ (del Giorgio et al. 1997, Biddanda et al. 2001 ) - suggest that on average $\sim 2$ to $36 \%$ of the total community respiration is due to $\mathrm{BR}$. Others have reported BR accounting for the bulk of the total community respiration in oligotrophic waters (Sherr \& Sherr 1996, Biddanda \& Cotner 2002). However, for meso-eutrophic waters such as Muskegon Lake, the consensus (del Giorgio et al. 1997, Biddanda et al. 2001, Navarro et al. 2004) is that the contribution of bacteria to plankton respiration is relatively less but still considerable.

\section{Muskegon Lake metabolism rate comparisons to other aquatic ecosystems}

Sampling during the underrepresented winter months yielded the full seasonality of Muskegon Lake. Thus, we were able to accurately determine annual metabolism rates of GPP, $R$ and NCP (Table 3). Muskegon Lake had a positive NCP value of $28 \pm 6 \mathrm{mg} \mathrm{C}^{-1} \mathrm{yr}^{-1}$, indicating that there is the potential for carbon accumulation/sedimentary deposition within Muskegon Lake or export to Lake Michigan. Marko et al. (2013) noted that Muskegon Lake retains nutrients before they plume out into Lake Michigan. Muskegon Lake operates as a nutrient filter, but it affects the surrounding watershed,

Table 3. Average $( \pm \mathrm{SE})$ daily and annual planktonic productivity rates in Muskegon Lake for the metabolic index of gross primary production (GPP), respiration $(R)$ and net community production (NCP)

\begin{tabular}{|c|c|c|}
\hline $\begin{array}{l}\text { Metabolic } \\
\text { index }\end{array}$ & 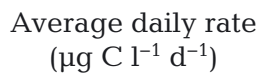 & $\begin{array}{c}\text { Yearly rate } \\
\left(\mathrm{mg} \mathrm{C}^{-1} \mathrm{yr}^{-1}\right)\end{array}$ \\
\hline GPP & $126 \pm 26$ & $46 \pm 9$ \\
\hline$R$ & $62 \pm 11$ & $23 \pm 4$ \\
\hline $\mathrm{NCP}$ & $78 \pm 18$ & $28 \pm 6$ \\
\hline
\end{tabular}


including Lake Michigan, with a wide-ranging influence on the regional fishery (Bhagat \& Ruetz 2011). The long-term ramifications of industry and urban development in and around Muskegon Lake remain to be determined (Steinman et al. 2008).

Median metabolic rates of Muskegon Lake fall within the range of available lake planktonic metabolism values reported in Duarte \& Agustí (1998) for GPP; $R$ and GPP: $R$ were slightly less than the median GPP and $R$ rates reported by Duarte \& Agustí (1998) and the median GPP: $R$ of Muskegon Lake (1.9) was slightly more than median GPP: $R$ of 1 reported by Duarte \& Agustí (1998). These comparisons suggest that a larger fraction of local phytoplankton production is available for trophic transfer in Muskegon Lake.

Ducharme-Riel et al. (2015) found winter respiration based on $\mathrm{CO}_{2}$ accumulation to range from 4.1 to $42.1 \mathrm{\mu g} \mathrm{C} \mathrm{l}^{-1} \mathrm{~d}^{-1}$ in 15 boreal lakes. This is comparable to the present study in this temperate lake, where winter measurements of respiration ranged from 24.3 to $32.8 \mu \mathrm{g} \mathrm{Cl}^{-1} \mathrm{~d}^{-1}$. In the summer months, defined by stratification, Ducharme-Riel et al. (2015) measured a respiration range of 9.3 to $54.5 \mu \mathrm{g} \mathrm{Cl}^{-1} \mathrm{~d}^{-1}$. Our summer respiration measurements were much higher compared to those measurements in Canadian lakes, and ranged from 89.7 to $198.8 \mathrm{\mu g} \mathrm{Cl}^{-1} \mathrm{~d}^{-1}$. Given that respiration rates double for every $1{ }^{\circ} \mathrm{C}$ increase in temperature, it is conceivable that respiration rates in warmer temperate lakes are going to be higher during the summer than those in relatively colder boreal lakes.

Similar patterns of autotrophy and heterotrophy were observed by Staehr \& Sand-Jensen (2007) in a small Danish lake (Frederiksborg Slotsso). However, Muskegon Lake differs in that the metabolic indices observed were less than those reported in other northern temperate lake ecosystems with ice cover. For example, mean annual GPP and $R$ rates for Muskegon Lake were $126 \pm 26$ and $62 \pm 11 \mu \mathrm{g} \mathrm{C} \mathrm{l}^{-1} \mathrm{~d}^{-1}$, respectively. Staehr \& Sand-Jensen (2007) reported a

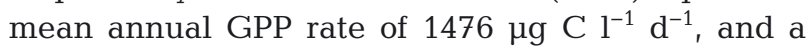
mean annual $R$ rate of $1032 \mu \mathrm{g} \mathrm{Cl}^{-1} \mathrm{~d}^{-1}$ in a 2003/ 2004 study in Danish lakes. The order of magnitude difference is likely a combination of differences in trophic status between Muskegon Lake and Frederiksborg Slotsso and the dystrophic nature of Muskegon Lake.

A more recent study in Lake Taihu, China (Liu et al. 2011) reported a mean annual GPP rate of $171 \mu \mathrm{g}$ $\mathrm{C}^{-1} \mathrm{~d}^{-1}$, and mean annual $R$ rate of $254 \mu \mathrm{g} \mathrm{C}^{-1} \mathrm{~d}^{-1}$. Although GPP rates for Muskegon Lake fall within the range of GPP rates reported by Liu et al. (2011), mean annual GPP rates for Muskegon Lake were lower, at $126 \pm 26 \mu \mathrm{g} \mathrm{Cl}^{-1} \mathrm{~d}^{-1}$. However, mean annual $R$ rates for Muskegon Lake were approximately 4

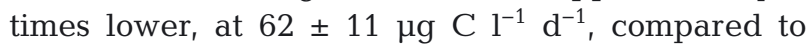
$254 \mu \mathrm{g} \mathrm{C}^{-1} \mathrm{~d}^{-1}$ reported by Liu et al. (2011), again pointing to the composition of the DOM pool as a critical factor regulating the cycling of carbon in Muskegon Lake.

Our results show that $R$ is nearly always smaller than GPP in Muskegon Lake, leading to greater GPP: $R$ ratios (Fig. 8). However, Carignan et al. (2000) found the same metabolic rate trend in oligotrophic and mesotrophic Canadian Shield lakes, with roughly the same median GPP: $R$ ratio as Muskegon Lake (1.9). Carignan et al. (2000) extrapolated daily $R$ rates based on a 4 to $7 \mathrm{~h}$ incubation time. Taking into account that planktonic respiration is always higher (20 to $30 \%$ ) at sunset than at sunrise, Carignan et al. (2000) concluded that they underestimated $R$ rates by biasing their sampling in the morning hours (07:00 to 10:00 h). Although this study also sampled in the morning (08:00 to $11: 00 \mathrm{~h}$ ), our daily $R$ rates were based on a $24 \mathrm{~h}$ incubation time. In general, the overall relatively low rates of $R$ observed in the present study may contribute to the increase in NCP during the summer-fall season.

\section{Physical, chemical and biological controls on lake metabolism}

The breakdown of summer stratification occurred in September at Site MC and October at Site MD. It seems plausible that this difference is due to wind exposure and depth. Site $\mathrm{MC}$ is shallower $(13 \mathrm{~m})$ and directly adjacent to Lake Michigan, and received sustained wind speeds of $13 \mathrm{~m} \mathrm{~s}^{-1} 10 \mathrm{~d}$ prior to sampling during the September cruise. In contrast, Site MD is deeper $(20 \mathrm{~m})$ and slightly more sheltered by sand dunes from prevailing Lake Michigan winds. Staehr et al. (2010) attributed wind exposure and depth to differences in stratification in 2 Danish lakes.

Depth may also be a major contributing factor to whole-lake accumulation of $\mathrm{CO}_{2}$, which can be fixed within the microbial loop (Ducharme-Riel et al. 2015). The differential mixing and subsequent near hypoxic conditions observed in the present study could similarly be attributed to depth. The greatest GPP: $R$ ratios were observed during breakdown of summer stratification. This result is contrary to 2 earlier studies that concluded stratification breakdown results in reoxygenation of the hypolimnion, and the accumulated reduced substances (including CDOM) 
are reoxidized, resulting in increased $R$ and reduced GPP: $R$ values for a short period of time (Staehr \& Sand-Jensen 2007, Staehr et al. 2010). Other studies have reported that mixing reduces GPP due to increased turbidity through resuspended sediments and decreased light penetration (Reynolds 2010).

Ducharme-Riel et al. (2015) reported higher volumetric accumulation of $\mathrm{CO}_{2}$ in the hypolimnion during the summer-fall season than during the winterspring period, and argued that enhanced benthic respiration may have been responsible for this 3.9-fold difference. The argument for such a large contribution of benthic $R$, however, is in contrast with the consensus in the literature that water column respiration is on average 5-fold greater than benthic respiration in lakes (Pace \& Prairie 2005). Using linear regression, Ducharme-Riel et al. (2015) determined that the predicted correlation of $R$ with $T$ was not significant, contrary to the findings in the present study. Moreover, in a separate study of northern headwater lakes, Finlay et al. (2015) reported a decrease in $\mathrm{CO}_{2}$ efflux with increasing atmospheric warming - suggesting that complex within-lake events may be confounding the usually expected positive correlation of $R$ with $T$. Clearly, more such studies are needed to clarify these conflicting findings.

The environmental variables identified as drivers of planktonic metabolism in the present study ( $T$, irradiance, phosphorus, ammonium, DOC and DO), are in general agreement with those reported in the literature for other freshwater systems (del Giorgio \& Peters 1994, Cole et al. 2000, Kalff 2002, Smith \& Prairie 2004, Staehr et al. 2010). Our study also stresses the importance of obtaining winter metabolism measurements to account for the full annual cycle, and sheds light on the complex interaction between physical and biological processes taking place in highly seasonal temperate lakes (Mortazavi et al. 2001).

\section{CONCLUSIONS}

The carbon cycle of freshwater ecosystems is a dynamic component of the global carbon cycle. Similar to marine estuaries, freshwater estuaries are hotspots of biogeochemical cycling, wherein mixing zone systems create complex habitats that sustain high productivity and biological diversity. In the present study, we summarized the results of a monthly study examining year-round changes in carbon and nutrient inventories and plankton community metabolism in Muskegon Lake - a Great Lakes estuary occurring at the terminus of a $\sim 7000 \mathrm{~km}^{2}$ watershed that connects directly to Lake Michigan, the second largest of the North American Great Lakes.

We found that the surface waters of Muskegon Lake were net autotrophic during all but the winter months under ice cover, when close carbon balance or even slight net heterotrophy prevailed. Approximately $6 \%$ of GPP and $12 \%$ of $R$ occurred during the winter months. However, an overall positive annual $\mathrm{NCP}$ rate of $\sim 28 \mathrm{mg} \mathrm{C}^{-1} \mathrm{yr}^{-1}$ that peaks during summer-fall makes the surface waters of Muskegon Lake a net sink for carbon on an annual basis. Concurrently measured annual heterotrophic bacterial production ( $5 \mathrm{mg} \mathrm{C}^{-1} \mathrm{yr}^{-1}$ ) represented a substantial fraction of NPP.

Year-round measurements provide an improved picture of the strong seasonality in the carbon cycle of lakes and the environmental forces that drive it. For example, the observation of an annual cycle of metabolism (with large summer autotrophy and a tendency during the winter for close carbon balance or even slight winter heterotrophy) helps explain why Muskegon Lake is a zone of optimum net productivity in the watershed (Ogdahl et al. 2010, Weinke et al. 2014, Dila \& Biddanda 2015), contributing to one of the most productive summer-fall fisheries in the state of Michigan (Bhagat \& Ruetz 2011).

Land-margin coastal ecosystems are emerging as key hotspots in the global carbon cycle. It is conceivable that every watershed in the world has such 'Goldilocks zones' where productivity is maximized by optimal terrigenous inputs, organic matter and inorganic nutrient recycling, hydrological retention times, etc. Future time series studies should seek to track such biogeochemical hotspots and hot moments in the Earth's coastal ecosystems (McClain et al. 2003), and strive to explain the underlying mechanisms.

Acknowledgements. This paper was part of the thesis requirement for A.L.D.'s MSc thesis in biology with emphasis in aquatic science at Grand Valley State University (GVSU). A.L.D. is thankful to her thesis committee (Drs. Eric Snyder and Rick Rediske) and those who assisted with the research project (Deb Dila, Scott Kendall, Brian Scull, Maggie Weinert, Matt Altenritter, Jordan Allison, Travis Ellens, Jessica Higgins, Billy Keiper, Kaitlyn Driza and Kurt Thompson). A.L.D. also thanks Dr. Erik Smith, Dr. Charlie Martin, Ashley Riggs, Olivia DeMeo and Susan Denham from the University of South Carolina for their support with thesis writing. This research was funded by an Annis Water Resources Institute-GVSU graduate assistantship, a Michigan Space Grant Consortium (MSGC) graduate fellowship, a GVSU Presidential Grant to A.L.D., and a MSGC Research Seed Grant to B.A.B. Lastly, we are grateful to 3 anonymous AME reviewers for their many constructive criticisms that substantially improved the quality of the manuscript. 


\section{LITERATURE CITED}

APHA (American Public Health Association) (1998). Standard methods for examination of water and wastewater. American Public Health Association, Washington, DC

> Aufdenkampe AK, Mayorga E, Raymond P, Melack J and others (2011) Riverine coupling of biogeochemical cycles between land, oceans, and atmosphere. Front Ecol Environ 9:53-60

Battin TJ, Luyssaert S, Kaplan L, Aufdenkampe A, Richter A, Tranvik L (2009) The boundless carbon cycle. Nat Geosci 2:598-600

Beisner BE, Lisa Dent C, Carpenter SR (2003) Variability of lakes on the landscape: roles of phosphorus, food webs and dissolved organic carbon. Ecology 84:1563-1575

Bennion H, Smith MA (2000) Variability in the water chemistry of shallow ponds in southeast England, with special reference to the seasonality of nutrients and implications for modeling trophic status. Hydrobiologia 436: 145-158

Bertilsson S, Burgin A, Carney C, Fey S and others (2013) The under-ice microbiome of seasonally frozen lakes. Limnol Oceanogr 58:1998-2012

> Bhagat Y, Ruetz C (2011) Temporal and fine scale spatial variation in fish assemblage structure in a drowned river mouth system of Lake Michigan. Trans Am Fish Soc 140: 1429-1440

Biddanda BA, Cotner JB (2002) Love handles in aquatic ecosystems: role of dissolved organic carbon drawdown resuspended sediments, and terrigenous inputs in the carbon balance of Lake Michigan. Ecosystems 5:431-445

Biddanda BA, Opsahl S, Benner R (1994) Plankton respiration and carbon flux through bacterioplankton on the Louisiana shelf. Limnol Oceanogr 39:1259-1275

> Biddanda BA, Ogdahl M, Cotner JB (2001) Dominance of bacterial metabolism in oligotrophic relative to eutrophic waters. Limnol Oceanogr 46:730-739

- Borges AV, Darcahmbeau F, Teodoru C, Marwick T and others (2015) Globally significant greenhouse-gas emissions form African inland waters. Nat Geosci 8:637-644

- Bot PVM, Colijn F (1996) A method for estimating primary production from chlorophyll concentrations with results showing trends in the Irish Sea and the Dutch coastal zone. ICES J Mar Sci 53:945-950

- Campbell JL, Mitchell MJ, Groffman PM, Christenson LM Hardy JP (2005) Winter in northeastern North America: a critical period for ecological processes. Front Ecol Environ 3:314-322

> Carignan R, Planas D, Vis C (2000) Planktonic production and respiration in oligotrophic Shield lakes. Limnol Oceanogr 45:189-199

Carter GS, Nalepa TF, Rediske RR (2006) Status and trends of benthic populations in a coastal drowned river mouth lake of Lake Michigan. J Gt Lakes Res 32:578-595

Cole JJ, Pace ML, Carpenter ST, Kitchell JT (2000) Persistence of net heterotrophy in lakes during nutrient addition and food web manipulation. Limnol Oceanogr 45: 1718-1730

> Cole JJ, Findlay S, Pace ML (1988) Bacterial production in fresh and saltwater ecosystems: a cross-system overview. Mar Ecol Prog Ser 43:1-10

Cole JJ, Carpenter ST, Kitchell JT, Pace ML (2002) Pathways of organic carbon utilization in small lakes: results from a whole lake ${ }^{13} \mathrm{C}$ addition and coupled model. Limnol Oceanogr 47:1664-1675
Cole JJ, Prairie YT, Caraco NF, McDowell WH and others (2007) Plumbing the global carbon cycle: integrating inland waters into the terrestrial carbon budget. Ecosystems 10:171-184

Cuthbert ID, del Giorgio P (1992) Toward a standard method of measuring color in freshwater. Limnol Oceanogr 37: $1319-1326$

del Giorgio PA, Peters RH (1994) Patterns in planktonic P:R ratios in lakes: influence of lake trophy and dissolved organic carbon. Limnol Oceanogr 39:772-787

del Giorgio PA, Williams PJ leB (2005) Respiration in aquatic ecosystems. Oxford University Press, Oxford

del Giorgio PA, Prairie YT, Bird DF (1997) Coupling between rates of bacterial production and the abundance of metabolically active bacteria in lakes, counted using CTC reduction and flow cytometry. Microb Ecol 34: 144-154

Dila DK, Biddanda BA (2015). From land to lake: contrasting microbial processes across a Great Lakes gradient of organic carbon and inorganic nutrient inventories. J Gt Lakes Res 41(Suppl 3):75-85

Dillon PJ, Molot LA (1997) Effect of landscape form on export of dissolved organic carbon, iron, and phosphorus from forested stream catchments. Water Resour Res 33: 2591-2600

Duarte CM, Agustí S (1998) The $\mathrm{CO}_{2}$ balance of unproductive aquatic ecosystems. Science 281:234-236

Ducharme-Riel V, Vachon D, del Giorgio PA, Prairie YT (2015) The relative contribution of winter under-ice and summer hypolimnetic $\mathrm{CO}_{2}$ accumulation to the annual $\mathrm{CO}_{2}$ emissions from northern lakes. Ecosystems 18: 547-559

Ducklow HW, Carlson CA (1992) Oceanic bacterial production. Adv Microb Ecol 12:113-181

Elser JJ, Andersen T, Baron JS, Bergström AK and others (2009) Shifts in lake N:P stoichiometry and nutrient limitation driven by atmospheric nitrogen deposition. Science 326:835-837

Findlay S, Pace ML, Lints D, Howe K (1992) Bacterial metabolism of organic carbon in the tidal freshwater Hudson Estuary. Mar Ecol Prog Ser 89:147-153

Finlay K, Vogt RJ, Bogard MJ, Wissel B, Tutolo BM, Simpson GL, Leavitt PR (2015) Decrease in $\mathrm{CO}_{2}$ efflux from northern hardwater lakes with increasing atmospheric warming. Nature 519:215-218

C Gergel SE, Turner MG, Kratz TK (1999) Dissolved organic matter as an indicator of the scale of watershed influence on lakes and rivers. Ecol Appl 9:1377-1390

Hanson PC, Bade DL, Carpenter SR, Kratz TK (2003) Lake metabolism: relationships with dissolved organic carbon and phosphorus. Limnol Oceanogr 48:1112-1119

Herdendorf CE (1990) Great Lakes estuaries. Estuaries 13: 493-503

Hobbie JE, Daley RJ, Jasper S (1977) Use of nucleopore filters for counting bacteria by epifluorescence microscopy. Appl Environ Microbiol 33:1225-1228

Kalff J (2002) Limnology: inland water ecosystems. Prentice Hall, Upper Saddle River, NJ

Karl DM, Laws EA, Morris P, Williams PJ leB, Emerson S (2003) Global carbon cycle (communication arising): metabolic balance of the open sea. Nature 426:32

Kemp WE, Smith EM, Marvin-DiPasquale M, Boynton WR (1997) Organic carbon balance and net ecosystem metabolism in Chesapeake Bay. Mar Ecol Prog Ser 150: 229-248 
Kirk JTO (1994) Light and photosynthesis in aquatic ecosystems, 2nd edn. Cambridge University Press, Cambridge

> Larson JH, Trebitz A, Steinman A, Wiley M and others (2013) Great Lakes rivermouth ecosystems: scientific synthesis and management implications. J Gt Lakes Res 39:513-524

Liu X, Wu Q, Chen Y, Dokulil M (2011) Imbalance of plankton community metabolism in eutrophic Lake Taihu, China. J Gt Lakes Res 37:650-655

Marko KM, Rutherford E, Eadie B, Johengen T, Lansing M (2013) Delivery of nutrients and seston form Muskegon River watershed to nearshore Lake Michigan. J Gt Lakes Res 39:672-681

> McClain ME, Boyer EW, Dent CL, Gergel SE and others (2003) Biogeochemical hot spots and hot moments at the interface of terrestrial and aquatic ecosystems. Ecosystems 6:301-312

- Mitsch WJ, Zang L, Anderson CJ, Altor AE, Hernandez ME (2005) Creating riverine wetlands: ecological succession nutrient retention, and pulsing effects. Ecol Eng 25 510-527

Mortazavi B, Iverson RL, Huang W (2001) Dissolved organic nitrogen and nitrate in Apalachicola Bay, Florida: spatial distributions and monthly budgets. Mar Ecol Prog Ser 214:79-91

- Navarro N, Agustí S, Duarte CM (2004) Plankton metabolism and dissolved organic carbon use in the Bay of Palma, NW Mediterranean Sea. Aquat Microb Ecol 37 47-54

Odum HT (1956) Primary production in flowing waters. Limnol Oceanogr 1:102-117

> Odum HT (1957) Trophic structure and production of Silver Springs, Florida. Ecol Monogr 27:55-112

Ogdahl ME, Lougheed VL, Stevenson RJ, Steinman AD (2010) Influences of multi-scale habitat on metabolism in a coastal Great Lakes watershed. Ecosystems 13: 222-238

Pace ML, Prairie YT (2005) Respiration in lakes. In: del Giorgio $\mathrm{P}$, Willams PJ leB (eds) Respiration in aquatic ecosystems. Oxford University Press, Oxford, p 103-121

> Porter KG, Saunders PA, Haberyan KA, Macubbin AE, Jacobson TR, Hodson RE (1996) Annual cycle of autotrophic and heterotrophic production in a small, monomictic Piedmont Lake: analog for the effects of climatic warming on dimictic lakes. Limnol Oceanogr 41: 1041-1051

Reynolds CS (2010) Biological-physical interactions. In Likens GE (ed) Biogeochemistry of inland waters. Academic Press, San Diego, CA, p 189-195

Robinson C (2008) Heterotrophic bacterial respiration. In Kirchman DL (ed) Microbial ecology of the oceans, 2nd edn. John Wiley \& Sons, Hoboken, NJ, p 299-335

Salonen K, Leppäranta M, Viljanen M, Gulati RD (2009) Per-

Editorial responsibility: Robert Sanders,

Philadelphia, Pennsylvania, USA spectives in winter limnology: closing the annual cycle of freezing lakes. Aquat Ecol 43:609-616

Schwaerter S, Sondergaard M, Riemann B, Jensen LM (1988) Respiration in eutrophic lakes: the contribution of bacterioplankton and bacterial growth yield. J Plankton Res 10:515-531

Sherr EB, Sherr BF (1996) Temporal offset in oceanic production and respiration processes implied by seasonal changes in atmospheric oxygen: the role of heterotrophic microbes. Aquat Microb Ecol 11:91-100

Simon M, Azam F (1989) Protein content and protein synthesis rates of planktonic marine bacteria. Mar Ecol Prog Ser 51:201-213

Smith SV, Hollibaugh JT (1997) Annual cycle and interannual variability of ecosystem metabolism in a temperate climate embayment. Ecol Monogr 67:509-533

Smith EM, Prairie YT (2004) Bacterial metabolism and growth efficiency in lakes: the importance of phosphorus availability. Limnol Oceanogr 49:137-147

Sommer U, Gliwicz ZM, Lampert W, Duncan A (1986) The PEG-model of seasonal succession of planktonic events in lakes. Arch Hydrobiol 106:433-471

Staehr PA, Sand-Jensen K (2007) Temporal dynamics and regulation of lake metabolism. Limnol Oceanogr 52: 108-120

Staehr PA, Sand-Jensen K, Raun AL, Nilsson B, Kidmose J (2010) Drivers of metabolism and net heterotrophy in contrasting lakes. Limnol Oceanogr 55:817-830

Steinman AD, Ogdahl M, Rediske R, Ruetz CR, Biddanda BA, Nemeth L (2008) Current status and trends in Muskegon Lake, Michigan. J Gt Lakes Res 34:169-188

Tranvik LJ, Downing JA, Cotner JB, Loiselle SA and others (2009) Lakes and reservoirs as regulators of carbon cycling and climate. Limnol Oceanogr 54:2298-2314

Tulonen T, Kankaala P, Ojala A, Arvola L (1994) Factors controlling production of phytoplankton and bacteria under ice in a humic, boreal lake. J Plankton Res 16: 1411-1432

Wehr JD, Petersen J, Findlay S (1999) Influence of three contrasting detrital carbon sources on planktonic bacterial metabolism in a mesotrophic lake. Microb Ecol 37:23-35

Weinke AD, Kendall ST, Kroll DJ, Strickler EA and others (2014) Systematically variable planktonic carbon metabolism along a land-to-lake gradient in a Great Lakes coastal zone. J Plankton Res 36:1528-1542

Welch HE, Bergmann MA (1985) Winter respiration of lakes at Saqvaqjuac, NWT. Can J Fish Aquat Sci 42:521-528

Wetzel RG, Likens GE (2000). Limnological analyses, 3rd edn. Springer-Verlag, New York, NY

Williamson CE, Morris DP, Pace ML, Olson OG (1999) Dissolved organic carbon and nutrients as regulators of lake ecosystems: resurrection of a more integrated paradigm. Limnol Oceanogr 44:795-803

Submitted: December 9, 2015; Accepted: June 21, 2016

Proofs received from author(s): August 26, 2016 